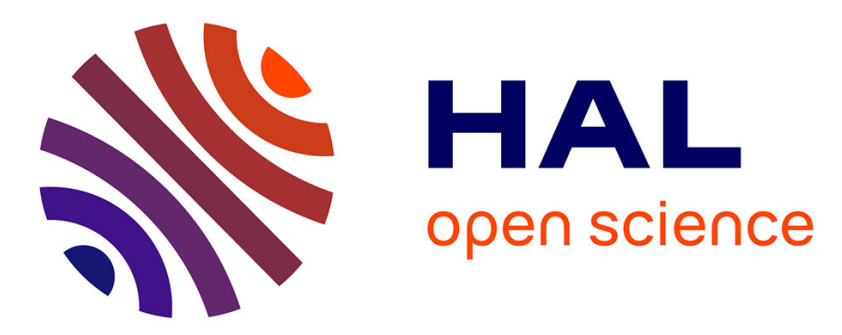

\title{
Positive effects of plant association on rhizosphere microbial communities depend on plant species involved and soil nitrogen level
}

Barbara Pivato, David Bru, Hugues Busset, Florence Deau, Annick Matejicek, Laurent Philippot, Delphine Moreau

\section{To cite this version:}

Barbara Pivato, David Bru, Hugues Busset, Florence Deau, Annick Matejicek, et al.. Positive effects of plant association on rhizosphere microbial communities depend on plant species involved and soil nitrogen level. Soil Biology and Biochemistry, 2017, 114, pp.1-4. 10.1016/j.soilbio.2017.06.018 . hal02619943

\section{HAL Id: hal-02619943 \\ https://hal.inrae.fr/hal-02619943}

Submitted on 25 May 2020

HAL is a multi-disciplinary open access archive for the deposit and dissemination of scientific research documents, whether they are published or not. The documents may come from teaching and research institutions in France or abroad, or from public or private research centers.
L'archive ouverte pluridisciplinaire HAL, est destinée au dépôt et à la diffusion de documents scientifiques de niveau recherche, publiés ou non, émanant des établissements d'enseignement et de recherche français ou étrangers, des laboratoires publics ou privés. 


\title{
Positive effects of plant association on rhizosphere microbial communities depend on plant species involved and soil nitrogen level
}

\author{
Barbara Pivato*, David Bru, Hugues Busset, Florence Deau, Annick Matejicek, \\ Laurent Philippot, Delphine Moreau
}

Agroécologie, AgroSup Dijon, INRA, Univ. Bourgogne Franche-Comté, F-21000 Dijon, France

\section{A R T I C L E I N F O}

\section{Article history:}

Received 26 January 2017

Received in revised form

7 June 2017

Accepted 16 June 2017

Available online 4 July 2017

\section{Keywords:}

Plant-microbe interaction

Rhizosphere

Plant association

Nitrogen

\begin{abstract}
A B S T R A C T
How plant species associations affect the rhizosphere microbiota, in comparison to each plant species, has been overlooked. Here we investigated how bi-species plant associations affect total bacterial and $\mathrm{N}$ cycling microbial communities (nitrate reducers and ammonia-oxidizers), as an example of functional communities, at low and high soil $\mathrm{N}$ levels. At low $\mathrm{N}$ level, the total bacterial abundance in the rhizosphere of the bi-species associations was significantly higher than that of either plant on its own for half of the bi-species associations. For the other associations, the bacterial abundance was not different from the corresponding mono-species cultures. The abundance of several N-cycling guilds was also enhanced by some of the bi-species associations with increases of up to $125 \%$ and no negative effects were recorded, which highlights the importance of plant diversity in agro-ecosystems.
\end{abstract}

(c) 2017 Elsevier Ltd. All rights reserved.
Understanding how plants are shaping microbial communities and their activities is a key for harnessing the rhizosphere microbiome and enhancing the beneficial plant-microbe interactions in agroecosystems (De Vrieze, 2015; Lareen et al., 2016). Different root exudates, such as the phytohormone salicylic acid (Lebeis et al., 2015 ) or the nitrification inhibitor brachialactone (Subbarao et al., 2009), and also other root traits (Cantarel et al., 2015), or Nrelated plant traits (Moreau et al., 2015) modulate the structure or the activity of the rhizosphere microbiome.

The vast majority of these studies focused on a single plant species (review in Bakker et al., 2013; Philippot et al., 2013). However, recent studies found plant species richness and community composition to be also important drivers of total microbial communities (e.g. microbial biomass, activity, structure) and functional communities as those involved in soil N-cycling (McGill et al., 2010; Eisenhauer et al., 2013; Le Roux et al., 2013; Strecker et al., 2015, 2016). Nevertheless, how these plant species associations affect soil microbial community structure and function, in comparison to each individual plant species, remains unclear. For example, are the abundance and structure of microbial communities in plant species associations similar to those of either individual plant species? Or can interactions between plant species

\footnotetext{
* Corresponding author.

E-mail address: barbara.pivato@inra.fr (B. Pivato).
}

increase the abundance of rhizosphere microbial communities in comparison to either plant species on its own?

Here, we analyzed the responses of soil microbial communities to mono- and bi-species plant associations, considering four monocotyledonous species, on both total and N-cycling microbial communities at low and high soil $\mathrm{N}$ levels. We focused on total bacteria as well as on the nitrate reducing and ammonia-oxidizing communities due to their role in the availability of nitrate and ammonium, which are major plant nutrients.

Our hypothesis was that bi-species associations lead to a different rhizosphere condition than mono-species associations, which can result in an increased abundance of microbial communities (positive effect) than each correspondent mono-species.

A greenhouse experiment was conducted using three weed species (Alopecurus myosuroides, Apera spica-venti and Vulpia myuros) and one crop species (Triticum aestivum cv. Caphorn). Four plants were cultivated in each pot, in either mono-species cultures (i.e. four plants of the same species) or bi-species cultures (i.e. two plants of two species), with three replicate pots per treatment. Pots were previously filled with a Cambisol collected in a grassland from a Long Term Observatory near Lusignan site [France: $46^{\circ} 25^{\prime} 12.91^{\prime \prime} \mathrm{N}$; $0^{\circ} 07^{\prime} 29.35^{\prime \prime} \mathrm{E}$ ] (soil properties are presented in Supplementary information, Table 1 ). The pots were filled with clay beads and soil and kept at $70 \%$ of the water holding capacity for a week before the pre-germinated seedling transplantation. All 
mono- and bi-species pots were weighted individually three times per day and automatically watered with nutrient solutions as described in Moreau et al. (2015) at two contrasted N concentrations: $0(\mathrm{~N}-)$ or $14 \mathrm{mmol} / \mathrm{L}(\mathrm{N}+)$ of nitrate, in order to reach $70 \%$ of water holding capacity in each pot. The air temperature was $21.8 \pm 0.8{ }^{\circ} \mathrm{C}$, and the incident photosynthetically active radiation was $20.3 \pm 4.8 \mathrm{~mol} \mathrm{~m}-2 \mathrm{~d}-1$, with a $16 \mathrm{~h}$ photoperiod. Eighty-four days after seedling transplantation, the shoot part of the plants was harvested and shoot biomass per pot was determined after drying ( $48 \mathrm{~h}$ at $80^{\circ} \mathrm{C}$ ). The rhizosphere soil was sampled from the four root systems as a whole of each pot as described by Offre et al. (2007), and suspended in $250 \mathrm{ml}$ of water in flasks instead of $100 \mathrm{ml}$. Soil DNA was extracted using the ISO-10063 procedure (Petric et al., 2011; Plassart et al., 2012). The genetic structure of rhizosphere bacterial communities was characterized by Automated Ribosomal Intergenic Spacer Analysis (A-RISA) (Ranjard et al., 2003), which exploits the variability in the length of the intergenic spacer (IGS) between the $16 \mathrm{~S}$ and $23 \mathrm{~S}$ sub-unit rRNA genes among different bacterial genotypes. PCR amplification of the 16S-23S intergenic spacer region in the rRNA operon was performed with a fluorescence-labeled forward primer and A-RISA-PCR fragments ranging in size from 400 to $1200 \mathrm{bp}$ were next discriminated and measured by using an automated electrophoresis system. DNA purification, quantification and A-RISA fingerprinting procedures were performed as previously described (Ranjard et al., 2003).

The abundances of the total bacterial and crenarcheal communities (16S rRNA), the bacterial and Thaumarchaeal ammonia oxidizers (AOB and $A O A$ ), and of the dissimilatory nitrate reducers (NarG and NapA) were determined by quantitative PCR (qPCR) (Bru et al., 2011). Plant shoot biomass per pot and qPCR abundances were submitted to two-way and one-way ANOVA followed by Tukey test. Non-Metric Multidimensional Scaling (NMDS), with Bray-Curtis as distance matrix, followed by Permutational MANOVA (PERMANOVA; Anderson, 2001), was used to analyze the genetic structure of bacterial communities. All statistical analyses were performed using the 3.2.1 version of $\mathrm{R}$ ( $\mathrm{R}$ Development Core Team, 2014). NMDS and PERMANOVA were run in Vegan package (Oksanen et al., 2012).

Shoot biomass of plants per pot were different depending both on plant association and $\mathrm{N}$ level (two way ANOVA with plant association and $\mathrm{N}$ level as factors; plant association: $\mathrm{F}-$ ratio $=11.02$ and $\mathrm{P}<0.0001$; $\mathrm{N}$ level: F-ratio $=1056.42$ and $\mathrm{P}<0.0001$; plant association $\times \mathrm{N}$ level: F-ratio $=9.63$ and $\mathrm{P}<0.0001$ ), but differences among plant associations were detected only in $\mathrm{N}+$ (Supplementary information, Fig. 1 ), with $T$. aestivum $(113.17 \pm 1.97 \mathrm{~g})$, [A. myosuroides + T. aestivum] $(105.35 \pm 2.85 \mathrm{~g})$ and $[$ A spicaventi $+T$. aestivum] $(104.43 \pm 4.13 \mathrm{~g})$ showing the highest biomass and $V$. myuros $(47.27 \pm 3.31 \mathrm{~g})$ and $[A$ spica-venti $+V$. myuros] the lowest $(52.1 \pm 16.74 \mathrm{~g})$. These results are in accordance with the different plant species affinities for $\mathrm{N}$, with $A$. spica-venti and $V$. myuros having lower $\mathrm{N}$ requirements than $A$. myosuroides and T. aestivum (Ellenberg, 1974; Moreau et al., 2013).

A strong impact of soil $\mathrm{N}$ level was also observed on the genetic structure of rhizosphere bacterial communities (PERMANOVA analysis, $\mathrm{P}=0.001$ ). In $\mathrm{N}$ - conditions only, the plant associations impacted differently the genetic structure of rhizosphere bacterial communities (Fig. 1), and this is probably due to enhanced competition for $\mathrm{N}$ between plant roots and rhizosphere microorganisms, as reviewed by Kuzyakov and Xu (2013).

Plant associations strongly impacted the abundances of total bacterial and $\mathrm{N}$-cycling microbial communities, and this effect was even higher at $\mathrm{N}$ - than $\mathrm{N}+$ conditions (two and one way ANOVA, Supplementary information, Fig. 2).

In order to check the effect of bi-species associations on microbial communities abundances in comparison to their respective
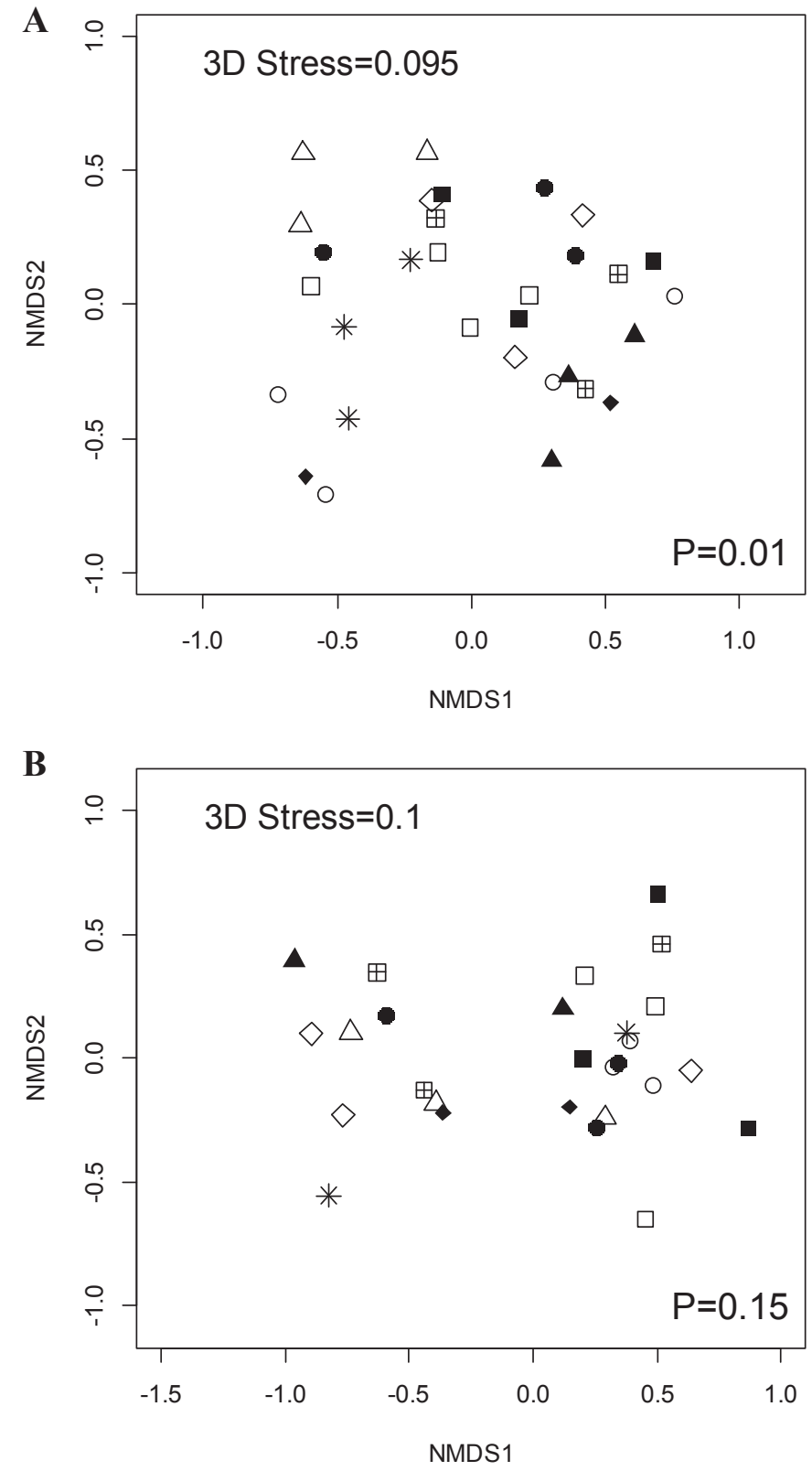

Fig. 1. Ordination plots of ARISA profiles from rhizosphere total bacterial communities, based on the Bray-Curtis similarity matrix: representation of $\mathrm{N}-(\mathrm{A})$ and $\mathrm{N}+(\mathrm{B})$ bacterial community structure. The quality of ordination is indicated by fair level of stress values, calculated in three dimension NMDS. Non-parametric MANOVA (PERMANOVA, Anderson, 2001) on Bray-Curtis distances was used to test if bacterial community structures differed significantly according to plant association for each $\mathrm{N}$ level and corresponding $\mathrm{p}$-values are reported at the bottom-right side of each graph.

Legend: $\triangle$ Alopecurus myosuroides (Am), $\diamond$ Apera spica-venti (Asv), $\mathbf{\square}$ Triticum aestivum (Ta), ○ Vulpia myuros $(\mathrm{Vm}), \boldsymbol{\Delta}[\mathrm{Am}+\mathrm{Asv}], \bullet[\mathrm{Am}+\mathrm{Ta}], \square[\mathrm{Am}+\mathrm{Vm}], \bullet[\mathrm{Asv}+\mathrm{Ta}], *$ $[$ Asv $+\mathrm{Vm}], \boxplus[\mathrm{Ta}+\mathrm{Vm}]$.

mono-species, further tests were performed on total bacterial and functional communities (Fig. 2). Significant effects were only detected at N- conditions (Fig. 2A, C, E, G and I).

In $\mathrm{N}$ - conditions, in half of the bi-species associations, the abundance of the total bacteria in the rhizosphere was higher than that of both corresponding mono-species (Fig. 2A). For the other bispecies associations, the abundance of the total bacterial community was similar to that obtained in the rhizosphere of at least one correspondent mono-species culture. A positive effect of bi-species associations was also observed on the abundance of the studied $\mathrm{N}$ - 

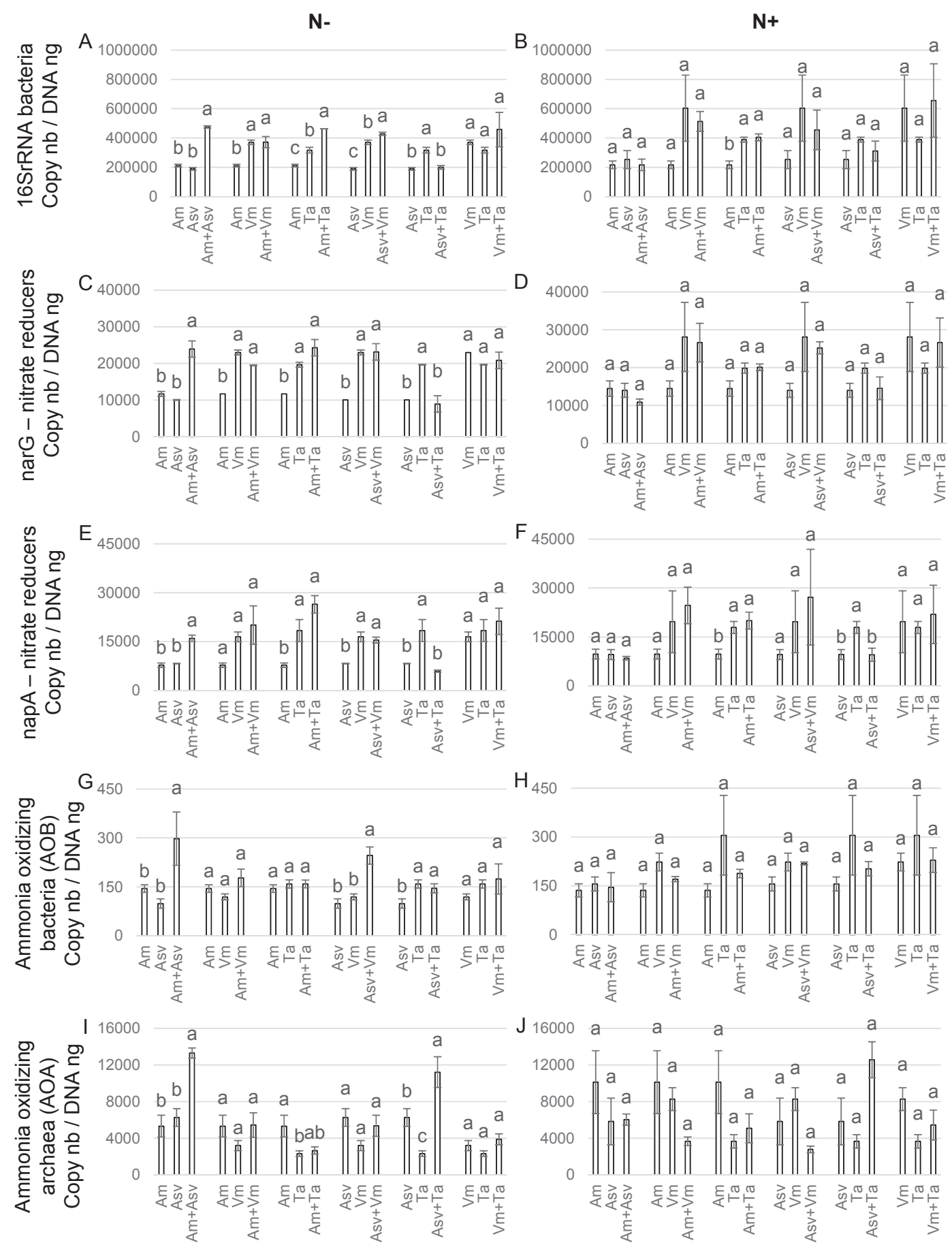

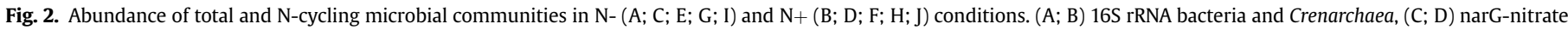

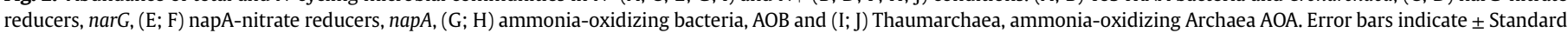

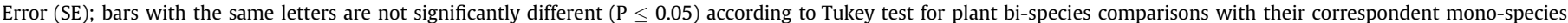
$(\mathrm{n}=3$ pots $)$ Am=Alopecurus myosuroides, Asv = Apera spica-venti, $\mathrm{Ta}=$ Triticum aestivum, and $\mathrm{Vm}=$ Vulpia myuros.

cycling microbial guilds but to a lesser extent. Only the association $[$ A. myosuroides + A. spica-venti] stimulated the abundances of both NarG- and NapA-nitrate reducing communities (Fig. 2C and E). Similarly, the abundances of both bacterial and archaeal ammonia oxidizers were increased by the association [A. myosuroides $+A$. spica-venti] while the association [A. spicaventi $+V$. myuros] and [A. spica-venti $+T$. aestivum] specifically stimulated the AOB and the AOA, respectively (Fig. 2G and I). An increasing body of literature is describing a niche partitioning between the AOA and AOB (Wessén et al., 2011; Prosser and Nicol, 2012). For example, a recent study showed that AOA were more abundant in the rhizosphere of exploitative plant species, whilst AOB abundance depended mostly on soil $\mathrm{pH}$ rather than plant traits (Thion et al., 2016).

No positive effects were detected in $\mathrm{N}+$ conditions (Fig. 2B, D, F, $\mathrm{H}$ and $\mathrm{J})$.

Our results showed that some bi-species associations increased the abundances of total or $\mathrm{N}$-cycling microbial communities in 
comparison with their respective mono-species associations. This positive effect suggests that plant species associations can provide more favorable conditions in the rhizosphere for the development of $\mathrm{N}$-cycling microbial communities, which could possibly lead to changes in the corresponding $\mathrm{N}$ - processes. These results are in line with previous observations in grassland systems that plant species richness beneficially affected soil microbial communities with, for example, increased microbial basal respiration and $\mathrm{C}$ biomass (Eisenhauer et al., 2013; Lange et al., 2014; Strecker et al., 2015, 2016). However, we found that the occurrence of a positive effect depended on both the soil $\mathrm{N}$ level and the plant species involved in the association. Specifically, the association $[$ A. myosuroides $+A$. spica-venti] showed a positive effect on the abundances of all the studied microbial communities. Similarly, Wardle \& Nicholson (1996) found the highest microbial biomass in bi-species than in mono-species associations. In contrast with natural grassland conditions, we observed a positive effect after 12 weeks of culture instead of four years (Eisenhauer et al., 2013; Strecker et al., 2016). Interestingly, no negative effects of bispecies associations on the abundances of the different bacterial communities were observed, and the abundance of microbial communities in bi-species cultures was always similar to at least one of the corresponding mono-species culture.

Overall, the increased abundances of both total and N-cycling microbial communities in some bi-species associations compared to the corresponding mono-species cultures indicate possible positive effects of plant species associations on the rhizosphere microbiome. Furthermore, we found that these positive effects of bi-species associations on microbial communities were modulated by soil-N level. Future research should aim at identifying plant traits underlying the effects of positive associations on their rhizosphere microbiota and at assessing if the resulting modifications of the rhizosphere microbiota impact in return the nitrogen nutrition of the plant associations.

\section{Acknowledgements}

Authors are grateful to Xavier Charrier and François Gastal for collecting and sending Lusignan soil, to the greenhouse staff in Dijon, Laure Avoscan, Catherine Barraud, François Dugué and Florence Strbik for technical help, and to Philippe Lemanceau for useful discussion. This work has been funded by the INRA Environmental and Plant Health department.

\section{Appendix A. Supplementary data}

Supplementary data related to this article can be found at http:// dx.doi.org/10.1016/j.soilbio.2017.06.018.

\section{References}

Anderson, M.J., 2001. A new method for non-parametric multivariate analysis of variance. Austral Ecology 26, 32-46.

Bakker, P.A.H.M., Berendsen, R.L., Doornbos, R.F., Wintermans, P.C.A., Pieterse, C.M.J. 2013. The rhizosphere revisited: root microbiomics. Frontiers in Plant Science 4. Article 165.

Bru, D., Ramette, A., Saby, N.P.A., Dequiedt, S., Ranjard, L., Jolivet, C., Arrouays, D., Philippot, L., 2011. Determinants of the distributions of nitrogen-cycling microbial communities at the landscape scale. The ISME Journal 5, 532-542.

Cantarel, A.A.M., Pommier, T., Desclos-Theveniau, M., Diquélou, S., Dumont, M., Grassein, F., Kastl, E.-M., Grigulis, K., Laîné, P., Lavorel, S., Lemauviel-Lavenant, S. Personeni, E., Schloter, M., Poly, F., 2015. Using plant traits to explain plantmicrobe relationships involved in nitrogen acquisition. Ecology 96, 788-799.

De Vrieze, J., 2015. The littlest farmhands. Science 349, 680-683.

Eisenhauer, N., Schulz, W., Scheu, S., Jousset, A., 2013. Niche dimensionality links biodiversity and invasibility of microbial communities. Functional Ecology 27, 282-288.

Ellenberg, H., 1974. Zeigerwerte der Gefässpflanzen Mitteleuropas Göttingen. Scr
Geobotanica 9, 1-97.

Kuzyakov, Y., Xu, X., 2013. Competition between roots and microorganisms for nitrogen: mechanisms and ecological relevance. New Phytologist 198, 656-669.

Lange, M., Habekost, M., Eisenhauer, N., Roscher, C., Bessler, H., Engels, C. Oelmann, Y., Scheu, S., Wilcke, W., Schulze, E.-D., Gleixner, G., 2014. Biotic and abiotic properties mediating plant diversity effects on soil microbial communities in an experimental grassland. PLoS One 9, e96182.

Lareen, A., Burton, F., Schäfer, P., 2016. Plant root-microbe communication in shaping root microbiomes. Plant Molecular Biology 90, 575-587.

Le Roux, X., Schmid, B., Poly, F., Barnard, R.L., Niklaus, P.A., Guillaumaud, N., Habekost, M., Oelman, Y., Philippot, L., Falcao Salles, J., Schloter, M., Steinbeiss, S., Weigelt, A., 2013. Soil environmental conditions and microbial build-up mediate the effect of plant diversity on soil nitrifying and denitrifying enzyme activities in temperate grassland. PLoS One 8, e61069.

Lebeis, S.L., Herrera Paredes, S., Lundberg, D.S., Breakfield, N., Gehring, J., McDonald, M., Malfatti, S., Glavina del Rio, T., Jones, C.D., Tringe, S.G., Dangl, J.L. 2015. Salicylic acid modulates colonization of the root microbiome by specific bacterial taxa. Science 349, 860-864.

McGill, B.M., Sutton-Grier, A.E., Wright, J.P., 2010. Plant traits diversity buffers variability in denitrification potential over changes in season and soil conditions. PLoS One 5, e11618.

Moreau, D., Milard, G., Munier-Jolain, N., 2013. A plant nitrophily index based on plant leaf area response to soil nitrogen availability. Agronomy for Sustainable Development 33, 809-815.

Moreau, D., Pivato, B., Bru, D., Busset, H., Deau, F., Faivre, C., Matejicek, A., Strbik, F., Philippot, L., Mougel, C., 2015. Plant traits related to nitrogen uptake influence plant-microbe competition. Ecology 96, 2300-2310.

Offre, P., Pivato, B., Siblot, S., Gamalero, E., Corberand, T., Lemanceau, P., Mougel, C., 2007. Identification of bacterial groups preferentially associated with mycorrhizal roots of Medicago truncatula. Applied and Environmental Microbiology 73, 913-921.

Oksanen, J., Blanchett, F.G., Kindt, R., Legendre, P., Minchin, P.R., O'Hara, R.B., Simpson, G.L., Solymos, P., Stevens, M.H.M., Wagner, H., 2012. Vegan: community ecology package. $\mathrm{R}$ package 2.0.3. Downloaded from. http://CRAN.Rproject.org/package=vegan.

Petric, I., Philippot, L., Abbate, C., Bispo, A., Chesnot, T., Hallin, S., Laval, K., Lebeau, T. Lemanceau, P., Leyval, C., Lindström, K., Pandard, P., Romero, E., Sarr, A., Schloter, M., Simonet, P., Smalla, K., Wilke, B.-M., Martin-Laurent, F., 2011. Interlaboratory evaluation of the ISO standard 11063 "soil quality e method to directly extract DNA from soil samples". Journal of Microbiological Methods 84, $454 \mathrm{e} 460$.

Philippot, L., Raaijmakers, J.M., Lemanceau, P., van der Putten, W.H., 2013. Going back to the roots: the microbial ecology of the rhizosphere. Nature Reviews Microbiology 11, 789-799.

Plassart, P., Terrat, S., Thomson, B., Griffiths, R., Dequiedt, S., Lelievre, M., Regnier, T., Nowak, V., Bailey, M., Lemanceau, P., Bispo, A., Chabbi, A., Maron, P.-A., Mougel, C., Ranjard, L., 2012. Evaluationof the ISOstandard11063DNAextraction procedure for assessing soil microbial abundance and community structure. PLoS One 7, e44279.

Prosser, J.I., Nicol, G.W., 2012. Archaeal and bacterial ammonia-oxidisers in soil: the quest for niche specialisation and differentiation. Trends in Microbiology 20, $523-531$.

R Development Core Team, 2014. R: a Language and Environment for Statistical Computing. R Foundation for Statistical Computing, Vienna, Austria.

Ranjard, L., Lejon, D.P.H., Mougel, C., Scherer, L., Merdinoglu, D., Chaussod, R., 2003. Sampling strategy in molecular microbial ecology: influence of soil sample size on DNA fingerprinting analysis of fungal and bacterial communities. Environmental Microbiology 5, 1111-1120.

Strecker, T., Barnard, R.L., Niklaus, P.A., Scherer-Lorenzen, M., Weigelt, A., Scheu, S. Eisenhauer, N., 2015. Effects of plant diversity, functional group composition, and fertilization on soil microbial properties in experimental grassland. PLoS One 10, e0125678.

Strecker, T., González Macé, O., Scheu, S., Eisenhauer, N., 2016. Functional Composition of Plant Communities Determines the Spatial and Temporal Stability of Soil Microbial Properties in a Long-term Plant Diversity Experiment. http:// dx.doi.org/10.1111/oik.03181. Oikos.

Subbarao, G.V., Nakahara, K., Hurtado, M.P., Ono, H., Moreta, D.E., Salcedo, A.F., Yoshihashi, A.T., Ishikawa, T., Ishitani, M., Ohnishi-Kameyama, M., Yoshida, M. Rondon, M., Rao, I.M., Lascano, C.E., Berry, W.L., Ito, O., 2009. Evidence for biological nitrification inhibition in Brachiaria pastures. Proceedings of the National Academy of Sciences 106, 17302-17307.

Thion, C.E., Poirel, J.D., Cornulier, T., De Vries, F.T., Bardgett, R.D., Prosser, J.I., 2016 Plant nitrogen-use strategy as a driver of rhizosphere archaeal and bacterial ammonia oxidiser abundance. FEMS Microbiology Ecology 92. http://dx.doi.org/ 10.1093/femsec/fiw91.

Wardle, D.A., Nicholson, K.S., 1996. Synergistic effects of grassland plant species on soil microbial biomass and activity: implications for ecosystem-level effects of enriched plant diversity. Functional Ecology 10, 410-416.

Wessén, E., Söderström, M., Stenberg, M., Bru, D., Hellman, M., Welsh, A. Thomsen, F., Klemedtson, L., Philippot, L., Hallin, S., 2011. Spatial distribution of ammonia-oxidizing bacteria and archaea across a 44-hectare farm related to ecosystem functioning. The ISME Journal 5, 1213-1225. 